Nig. J. Biotech. Vol. 38 (2) : 67-72 (Dec 2021)

ISSN: 01891731

Available online at

http://www.ajol.info/index.php/njb/index

and www.biotechsocietynigeria.org

DOI: https://dx.doi.org/10.4314/njb.v38i2.7

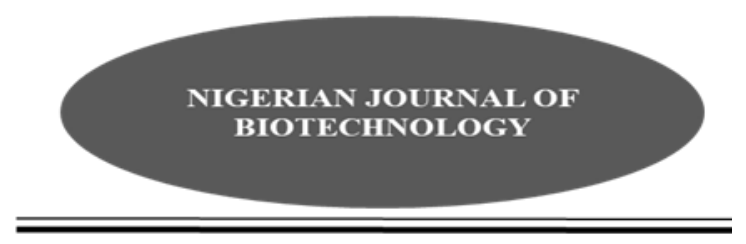

\title{
The Influence Of Metal Ions On Cellulolytic Activities Of Fungal Isolates From Palm Biomass
}

\author{
Onyia, D.C. ${ }^{1}$, Onyeneke, E.C. ${ }^{2}$, Okunwaye, $\mathrm{T}^{1}$, Okogbenin, E.0. ${ }^{1}$, Asiriuwa, \\ N.U. ${ }^{1}$, Obibuzor, J.U. $^{1}$, and Anemene, $\mathrm{H}^{\mathbf{1}}$. \\ ${ }^{* 1}$ Biochemistry Division, Nigerian Institute for Oil Palm Research (NIFOR), P.M.B. 1030, Benin City, Edo \\ State, Nigeria. \\ ${ }^{2}$ Biochemistry Department, Faculty of Life Sciences, University of Benin, P.M.B 1154, Benin City, Edo \\ State, Nigeria.
}

\begin{abstract}
Numerous metal ions and chemical compounds can influence the activity of some fungi. Some have inhibitory effects whereas others have enhancing effects. In this study, the effect of metallic chlorides; lead II chloride $\left(\mathrm{PbCl}_{2}\right)$, potassium chloride $(\mathrm{KCl})$, copper II chloride $\left(\mathrm{CuCl}_{2}\right)$, calcium II chloride $\left(\mathrm{CaCl}_{2}\right)$, manganese II chloride $\left(\mathrm{MnCl}_{2}\right)$, iron III chloride $\left(\mathrm{FeCl}_{3}\right)$ and mercury II chloride $\left(\mathrm{HgCl}_{2}\right)$ were evaluated for their influence on the cellulolytic activity of seven (7) fungal isolates at a concentration of $0.005 \mathrm{M}$ at $30^{\circ} \mathrm{C}$ for four (4) days using 3, 5dinitrosalicyclic acid (DNS) method. $\mathrm{CaCl}_{2}$ had the highest influence on the cellulolytic activity for all the fungal isolates as compared to the control. In the presence of $\mathrm{CaCl}_{2}$, Trichoderma species (C) showed a high cellulolytic activity of $2.28 \times 10^{-5} \mathrm{mmol} / \mathrm{min} / \mathrm{ml}$, Rhizopus, Trichoderma and Aspergillus species (A, B and E) had activities of $1.72 \times 10^{-5}, 1.65 \times 10^{-5}$ and $1.68 \times 10^{-5} \mathrm{mmol} / \mathrm{min} / \mathrm{ml}$ respectively. $\mathrm{HgCl}_{2}$ and $\mathrm{CuCl}_{2}$ had the least influenced on the cellulolytic activity of all the fungal isolates. This, therefore, suggests that calcium ion activates the cellulase activity of the fungal species while $\mathrm{HgCl}_{2}, \mathrm{PbCl}_{2}, \mathrm{KCl}, \mathrm{CuCl}_{2}, \mathrm{MnCl}_{2}$ and $\mathrm{FeCl}_{3}$ had a retarding effect on the cellulolytic activity.
\end{abstract}

Keywords: Metallic ions, Cellulolytic activity, Fungal isolates

Corresponding authors Email: onyiachimad@gmail.com; Phone: $+2347032266911,+2347034228511$.

\section{Introduction:}

Heavy metals have been shown to be one of the greatest hazardous pollutants in the environment brought about by human economic activities, both agricultural and non-agricultural (Goyer, 2001; On et al., 2005; Micó, et al., 2006). In the soil, they react with chemicals, accumulating in numerous forms with different bioavailability to plants (Singh and Kalamdhad, 2011). In natural concentrations, metals are generally crucial in the activities of living organisms, but frequently have noxious properties when in excess (Badura and Piotrowska-Seget, 2000; Singh and Kalamdhad,
2011). Furthermore, their existence in soil has a key influence on cell structure, growth and development, and the biological actions of soil microorganisms (Badura and Piotrowska-Seget, 2000; Tscherko et al., 2007; Hassn et al., 2014). Although heavy metals naturally transpire in the soil environment, currently there are many factors significantly fueling their increase, such as industrial activities, and imaginably most importantly, the increase of agricultural production using chemical-dependent farming methods (Lenart and Wolny-Koładka, 2013). Metals in soil are detected in different forms such 
as soluble metal complexes (sequestered to ligands), unrestricted metal ions, transferrable metal ions, precipitated or insoluble compounds such as oxides, carbonates and hydroxides. Heavy metal toxicity depends on their transfer from the affected soil to the organisms (Juste, 1988). The effect of metals not only depends on their total concentration but also on biological (e.g. solubilisation, biosorption and bioaccumulation) and physico-chemical (e.g pH, organic matter, clay content) factors (Berthelin, et al., 1995).

Lignocellulolytic enzymes include cellulases, hemicellulases, and ligninases, which individually break down cellulose, hemicellulose, and lignin, which majorly make up the plant cell wall, altogether called lignocellulose. Cellulases are engaged in countless areas in the industry, like in the textile (Simic, et al., 2015), detergents, animal feed, and vinification (Podrepsek, et al., 2012; Karmakar and Ray, 2011; Liete, et al., 2008; Graminha, et al., 2008). In the past, the prospects of these enzymes in breaking down cellulose from lignocellulosic remains has been studied broadly targeting glucose for use in cellulosic ethanol making (de Cassia Pereira, 2016).

The impact of metal ions on activities of enzymes can be from the water in the soil or as a result of reagents used during et al., industrial processes or also come from equipment corrosion (Oviedo and Rodríguez, 2003). Metal ions and chemical compounds may enhance cellulolytic activity. There are reports that metal ions such as $\mathrm{Hg}^{2+}$, $\mathrm{Cu}^{2+}, \mathrm{Zn}^{2+}, \mathrm{Mg}^{2+}, \mathrm{Fe}^{3+}, \mathrm{Mn}^{2+}, \mathrm{Ag}^{+}, \mathrm{Mn}^{2+}, \mathrm{K}^{+}$ partially or entirely inhibit cellulolytic activities, although metal ions like $\mathrm{Ca}^{2+}, \mathrm{Na}^{+}$and $\mathrm{Co}^{2+}$ enhance or moderately enhance cellulolytic activity (Bagga, et al.,1990; Yan and Lin,1997; Dutta, et al.,2008; Nazir, et al.,2009). Riou et al. (1998) considered the influence of several metal ions and detergents on cellulase generated by $A$. oryzae, and discovered that $\mathrm{Ag}^{+}, \mathrm{Hg}^{2+} \mathrm{Fe}^{3+}$, SDS, diethylpyrocarbonate, castanospermine, dithiothreitol slightly or entirely repressed the cellulolytic activity; while $\mathrm{Mn}^{2+}$ improved the activity. Furthermore, the level of cellulase produced by $A$. terreus $\mathrm{M} 11$ was enhanced on the addition of $\mathrm{Mn}^{2+}$; but $\mathrm{Hg}^{2+}, \mathrm{Cu}^{2+}, \mathrm{Pb}^{2+}$ and detergents to some extent reduced or repressed the cellulolytic activity (Gao, et al., 2008). Yang et al. (2008) established that the cellulase produced by Paecilomyces thermophila was meaningfully reduced by $\mathrm{Hg}^{2+}$; while the cellulolytic activity was extremely improved on addition of $\mathrm{Zn}^{2+}$ (Yang, et al., 2008).

The purpose of this study is to investigate the effect of selected metallic ions in the production of cellulase from fungi associated with palm biomass.

\section{Materials and Methods:}

\section{Sample Collection:}

Samples of palm pressed fibre (PPF), decaying empty fruit bunch (DEFB) and decaying roots of the oil palm tree were collected from the Nigerian Institute for Oil Palm Research (NIFOR) main station, Benin City, Nigeria.

\section{Isolation of Fungi and Preparation of Culture:}

The samples were cut and placed in McCartney bottles which contained $9 \mathrm{ml}$ of sterile distilled water. They were shaken vigorously on a vortex mixer for 10 minutes. Each McCartney bottle containing samples were serially diluted from which $1 \mathrm{ml}$ of $10^{1}$ to $10^{-5}$ dilutions were plated separately on Petri dish plates of potato dextrose agar (PDA), pH 6, containing $(0.02 \mathrm{~g}$ per $200 \mathrm{~mL}$ of medium) chloramphenicol. The plates were incubated aerobically at room temperature of $30^{\circ} \mathrm{C}$. The developing fungi colonies were aseptically subcultured into gelled prepared potato dextrose agar (PDA, Difco Laboratories, Detroit, USA) plates until pure cultures were gotten). Pure fungi isolated were stored in slants.

\section{Reagents and chemicals:}

Cellulose powder, PDA, and metallic salts; lead II chloride $\left(\mathrm{PbCl}_{2}\right)$, potassium chloride $(\mathrm{KCl})$, copper II chloride $\left(\mathrm{CuCl}_{2}\right)$, calcium II chloride $\left(\mathrm{CaCl}_{2}\right)$, manganese II chloride $\left(\mathrm{MnCl}_{2}\right)$, iron III chloride $\left(\mathrm{FeCl}_{3}\right)$ and mercury II chloride $\left(\mathrm{HgCl}_{2}\right)$ all of the analytical grades were purchased from Pyrex-IG Scientific Company, Benin City, Edo State, Nigeria.

Measurement of Cellulolytic Enzymes Activity: The fungi isolates were grown on Czapek-Dox broth (Lekh, et al., 2014). Czapek-Dox broth was prepared and amended with $1 \%$ cellulose, $0.005 \mathrm{M}$ each of the metal salts and distributed into $100 \mathrm{ml}$ conical flasks and the $\mathrm{pH}$ adjusted to 7.0 using $\mathrm{NaOH}$ and $\mathrm{HCl}$. After sterilization, the 
fungal spore were inoculated into it and incubated at $30^{\circ} \mathrm{C}$ for four (4) days on a rotary shaker at $120 \mathrm{rpm}$. The mycelia were harvested by filtering, and the filtrate centrifuged and assayed by DNS method to get the activity of the enzymes (Sivaramanan, 2014), each measured using UV spectrophotometer at $540 \mathrm{~nm}$.

\section{Dinitrosalicylic acid (DNS) method:}

The assessment of the reducing sugars in the samples was done using the DNS method. The DNS reagent is an alkaline solution of 3, 5dinitrosalicyclic acid and tartarate salt. On heating, the reducing sugars can reduce 3, 5dinitrosalicyclic acid to 3 amino-5-nitrosalicyclic acid, which appears orange-red in colour. The concentration of the colour is relative to the quantity of reducing sugars existing in the sample. The orange colour developed is compared to standards in a spectrophotometer at 540nm (Miller, 1959).

\section{Preparation of Dinitrosalicylic acid:}

DNS reagent was made by adding $1 \mathrm{~g} 3$, 5dinitrosalicylic acid (DNS) in $50 \mathrm{~mL}$ of distilled water. About $200 \mathrm{mg}$ crystalline phenol (elective) and $30 \mathrm{~g}$ of sodium potassium tartrate were poured into the solution turning the solution into yellow colour. Also, $20 \mathrm{~mL}$ of $2 \mathrm{~N} \mathrm{NaOH}$ was added producing a clear orange-yellow colour. The addition of distilled water was used to make up the stock solution to $100 \mathrm{~mL}$. The stock was stored in a refrigerator, to prevent deterioration (Miller, 1959).

\section{Results and Discussion}

Seven (7) fungal species were isolated from the palm biomass. The fungi isolates were identified, and labelled A-G. They are one Rhizopus, two Trichoderma, three Aspergillus and one Penicillium species.

In Fig 1 , it showed that isolate $C$ produced a higher cellulolytic activity of $5.97 \times 10^{-6}$ $\mathrm{mmol} / \mathrm{min} / \mathrm{ml}$ in the presences of $\mathrm{PbCl}_{2}$, followed by isolate $D\left(5.12 \times 10^{-6} \mathrm{mmol} / \mathrm{min} / \mathrm{ml}\right)$. Isolates $F$ and $\mathrm{G}$ produced cellulolytic activities of $5.0 \times 10^{-6}$ $\mathrm{mmol} / \mathrm{min} / \mathrm{ml}$ each. Isolate $A$ produced the lowest activity of $4.02 \times 10^{-6} \mathrm{mmol} / \mathrm{min} / \mathrm{ml}$, which is at variance with isolate $\mathrm{E}\left(4.75 \times 10^{-6}\right.$ $\mathrm{mmol} / \mathrm{min} / \mathrm{ml}$ ).
In the presence of $\mathrm{KCl}$, isolate $\mathrm{B}$ showed the highest cellulolytic activity of $9.88 \times 10^{-6}$ $\mathrm{mmol} / \mathrm{min} / \mathrm{ml}$; although isolate $C\left(6.71 \times 10^{-6}\right.$ $\mathrm{mmol} / \mathrm{min} / \mathrm{ml}$ ) cellulolytic activity was high but not significantly different when compared to $A$ $\left(6.34 \times 10^{-6}\right), \mathrm{D}\left(6.22 \times 10^{-6}\right), \mathrm{E}\left(5.61 \times 10^{-6}\right)$ and $\mathrm{F}\left(4.63 \times 10^{-6} \mathrm{mmol} / \mathrm{min} / \mathrm{ml}\right)$ respectively. Isolate $\mathrm{G}$ produced the lowest cellulolytic activity of 4.02 $\times 10^{-06} \mathrm{mmol} / \mathrm{min} / \mathrm{ml}$ when $\mathrm{KCl}$ was added, as compared to the control.

Isolate $\mathrm{F}$ caused the highest cellulolytic activity of $4.75 \times 10^{-6} \mathrm{mmol} / \mathrm{min} / \mathrm{ml}$ on addition of $0.005 \mathrm{M}$ of $\mathrm{CuCl}_{2}$ when compared to isolate $\mathrm{C}$ with activity of $4.51 \times 10^{-6} \mathrm{mmol} / \mathrm{min} / \mathrm{ml}$. Isolate A showed the lowest cellulolytic activity of $2.68 \times 10^{-6}$ $\mathrm{mmol} / \mathrm{min} / \mathrm{ml}$ when compared to isolates $B$ and $D$ with activities of $3.05 \times 10^{-6}$ and $3.29 \times 10^{-6}$ $\mathrm{mmol} / \mathrm{min} / \mathrm{ml}$ respectively.

On addition of $\mathrm{CaCl}_{2}$, the activities in all the fungal isolates were higher as compared to the other metal salts. Isolate $\mathrm{C}$ produced the highest cellulolytic activity of $2.28 \times 10^{-5} \mathrm{mmol} / \mathrm{min} / \mathrm{ml}$, followed by isolate $A\left(1.73 \times 10^{-5} \mathrm{mmol} / \mathrm{min} / \mathrm{ml}\right)$ when compared to isolates $B\left(1.76 \times 10^{-5}\right), E(1.68$ $\left.\times 10^{-5}\right), \quad F\left(1.61 \times 10^{-5}\right)$ and $G\left(1.56 \times 10^{-5}\right.$ $\mathrm{mmol} / \mathrm{min} / \mathrm{ml}$ ) respectively. Isolate $D$ caused the lowest cellulolytic activity of $1.05 \times 10^{-05}$ $\mathrm{mmol} / \mathrm{min} / \mathrm{ml}$.

When $\mathrm{MnCl}_{2}$ was added, isolate $\mathrm{C}$ produced the highest cellulolytic activity of $9.88 \times 10^{-6}$ $\mathrm{mmol} / \mathrm{min} / \mathrm{ml}$. Isolates A $\left(6.71 \times 10^{-6}\right), B(6.34$ $\left.\times 10^{-6}\right), \quad F\left(6.22 \times 10^{-6}\right)$ and $\mathrm{D}\left(5.6 \times 10^{-6}\right.$ $\mathrm{mmol} / \mathrm{min} / \mathrm{ml}$ ) produced a high cellulolytic activity. Isolate $\mathrm{E}$ produced the lowest cellulolytic activity of $4.02 \times 10^{-6} \mathrm{mmol} / \mathrm{min} / \mathrm{ml}$.

On addition of $\mathrm{FeCl}_{3}$, isolate $\mathrm{E}$ triggered the highest cellulolytic activity of $7.32 \times 10^{-6}$ $\mathrm{mmol} / \mathrm{min} / \mathrm{ml}$ when compared to isolate $\mathrm{F}(6.71$ $\left.\times 10^{-6} \mathrm{mmol} / \mathrm{min} / \mathrm{ml}\right)$. Isolate $B$ produced the lowest cellulolytic activity of $1.95 \times 10^{-6}$ $\mathrm{mmol} / \mathrm{min} / \mathrm{ml}$.

Isolate $\mathrm{B}$ produced the highest cellulolytic activity of $5.12 \times 10^{-6} \mathrm{mmol} / \mathrm{min} / \mathrm{ml}$ on addition of $\mathrm{HgCl}_{2}$ when compared to isolates $C\left(4.75 \times 10^{-6}\right)$ and $F$ $\left(3.9 \times 10^{-6} \mathrm{mmol} / \mathrm{min} / \mathrm{ml}\right)$. Isolate $A$ produced a lower cellulolytic activity of $2.8 \times 10^{-6}$ $\mathrm{mmol} / \mathrm{min} / \mathrm{ml}$ when compared to isolate $\mathrm{D}$ (3.05 $\mathrm{x} 10^{-6} \mathrm{mmol} / \mathrm{min} / \mathrm{ml}$ ). 
This study showed that all metal ions had different influence on the cellulolytic activity of the isolates compared to the control but the addition of $\mathrm{Ca}^{2+}$ increased the cellulolytic activities of the isolates. This suggests that $\mathrm{Ca}^{2+}$ has the capacity to stimulate the cellulolytic activity of the fungi, thus supporting the study of Bagga, et al., (1990), Sajith, et al., (2016) and Nazir, et al., (2009).
From this present study, $\mathrm{Pb}^{2+}, \mathrm{K}^{+}, \mathrm{Cu}^{2+}, \mathrm{Mn}^{2+}$, $\mathrm{Fe}^{3+}$ and $\mathrm{Hg}^{2+}$ lowered the cellulolytic activity when compared to the control. This suggests that the metallic ions have the ability to cause an inhibitory effect which is in accordance with the study of Sajith, et al., (2016) and Riou, et al., (1998). This results obtained is contrary to the study of Gao, et al., (2008), who reported that $\mathrm{Mn}^{2+}$ increased the cellulase production of $A$. terreus M11. However, $\mathrm{Hg}^{2+}, \mathrm{Cu}^{2+}$ and $\mathrm{Pb}^{2+}$ reduced the cellulase production as shown in Fig 1.
Key
$\mathrm{A}=$ Rhizopus species
$\mathrm{E}=$ Aspergillus species
$\mathrm{B}=$ Trichoderma species
$\mathrm{F}=$ Aspergillus species
$\mathrm{C}=$ Trichoderma species
$\mathrm{G}=$ Penicillium species
$\mathrm{D}=$ Aspergillus species

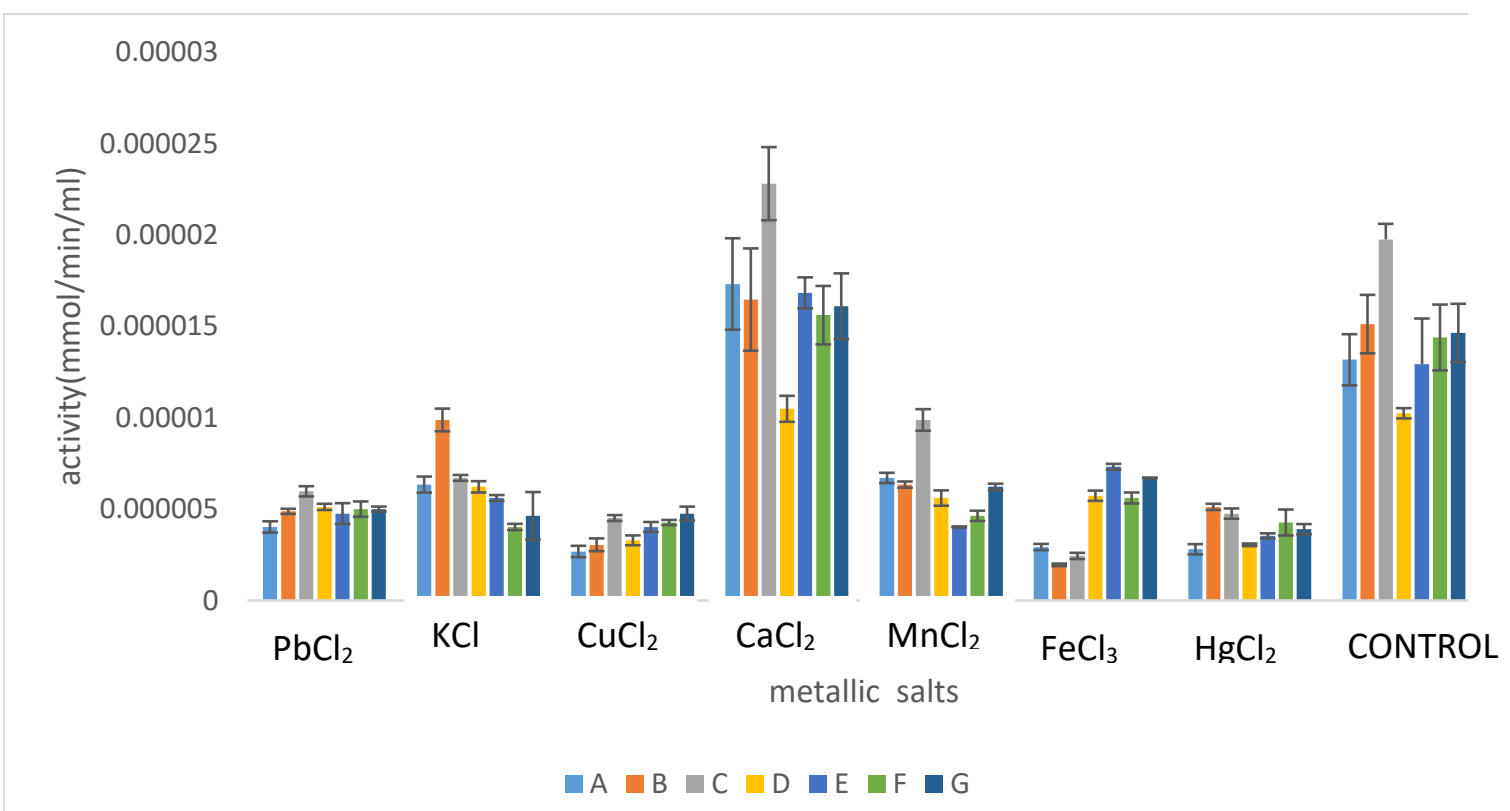

Fig.1: Cellulolytic activity of the fungi isolates

\section{Conclusion}

This work establishes the possibility of harnessing palm biomass which has been regarded as waste into a substrate for the growth of cellulolytic fungi. There is the need to optimize the conditions necessary for the production of cellulolytic fungi in other to attain optimum yield. In this study, calcium ion plays a major role in 
enhancing cellulolytic activity under the conditions studied. While the other metallic ions showed to be inhibitory under the same conditions.

\section{References}

Sivaramanan, S. (2014). Isolation of the cellulolytic fungi and the degradation on cellulosic agricultural wastes. JAIR, 2:8-17.

Sajith,S., Priji, P., Sreedevi, S and Benjamin, S. (2016). An overview of fungal cellulases with an industrial perspective. J.Nutri. and food Sci.6:115.

Dutta, T., Sahoo, R., Sengupta, R., Ray, S.S., Bhattacharjee, A. and Ghosh, S. (2008). Novel cellulases from an extremophilic filamentous fungi Penicillium citrinum: Production and characterization. JIMB, 35: 275-282.

Gao, J., Weng, H., Xi, Y., Zhu, D. and Han, S. (2008). Purification and characterization of a novel endo-beta-,4-glucanase from the thermoacidophilic Aspergillus terreus. Biotechnol. 30: 323-327.

Riou, C., Salmon, J.M., Vallier, M.J., Günata, Z. and Barre, P. (1998). Purification, characterization, and substrate specificity of a novel highly glucosetolerant B-glucosidase from Aspergillus oryzae. Appl. Environ. Microbiol., 64: 3607-3614.

Bagga, P.S., Sandhu, D.K. and Sharma, S. (1990). Purification and characterization of cellulolytic enzymes produced by Aspergillus nidulans. J. Appl. Bacteriol. 68: 61-68.

Yan, T.R. and Lin, C.L. (1997). Purification and characterization of a glucosetolerant betaglucosidase from Aspergillus niger CCRC 31494. Biosci. Biotechnol. Biochem. 61: 965-970.

Nazir, A., Soni, R., Saini, H., Manhas, R. and Chadha, B. (2009). Purification and characterization of an endoglucanase from Aspergillus terreus highly active against barley $B$ glucan and xyloglucan. World J. Microbiol. Biotechnol, 25: 1189-1197.
Yang, S., Jiang, Z., Yan, Q. and Zhu, H. (2008). Characterization of a thermostable extracellular beta-glucosidase with activities of exoglucanase and transglycosylation from Paecilomyces thermophila. J. Agric. Food Chem.56: 602-608.

Simic, K., Soljacic, I. and Pusic, T. (2015). Application of cellulases in the process of fishing (Uporaba celulaz $\mathrm{v}$ procesu plemenitenja). Tekstilec, 58, 47-56.

Podrepsek, G.H., Primozic, M., Knez, Z. and Habulin, M. (2012). Immobilization of cellulase for industrial production. Chem. Engr. Transact. 27:235-240.

Karmakar, M. and Ray, R.R. (2011).Current trends in research and applications of microbial cellulases. Res. J. Microbiol. 6: 41-53.

Oviedo, C. and Rodríguez, J. (2003). EDTA: The chelating agent under environmental scrutiny.Qum. Nova, 26: 901-905.

Leite, R.S.R., Alves-Prado, H.F., Cabral, H., Pagnocca, F.C., Gomes, E. and Da-Silva, R.

(2008). Production and characteristics comparison of crude $\beta$-glucosidases produced by microorganisms; Thermoascus aurantiacuse Aureobasidium pullulans in agricultural wastes. Enzyme Microb. Technol. 43: 391-395.

Graminha, E.B.N., Gonçalves, A.Z.L., Pirota, R.D.P.B., Balsalobre, M.A.A., Da Silva, R. and Gomes, E. (2008). Enzyme production by solidstate fermentation: Application to animal nutrition. Anim. Feed Sci. Technol. 144: 1-22.

Badura, L. and Piotrowska-Seget, Z. (2000). Heavy metals in the environment and their impact on soil microorganisms. Ecol. Chem. Eng., 7(11): 1135-1142.

Goyer, R. A. (2001). Toxic Effects of Metals. In: Klaassen, C. D. ( $2^{\text {nd }}$ ed.) Cassarett and Doull's Toxicology: The Basic Science of Poisons. McGraw-Hill, New York. 63 pp.

Hassn, W. A., Asaf, L. H. and Salih, M. S. M. (2014). Effect of heavy metals ions on growth, sporulation and pathogenicity of Isaria javanica = 
(Paecilomyces javanicus). Int. j. pure appl. sci. technol, 20(2): 1-7.

Kabata-Pendias, A. and Pendias, H. (2001). Trace Elements in Soils and Plants. CRC Press, Boca Raton, London.

Lenart, A. and Wolny-Koładka, K. (2013). The effect of heavy metal concentration and soil $\mathrm{pH}$ on the abundance of selected microbial groups within arcelormittal Poland steelworks in Cracow. Bull Environ Contam Toxicol, 90(1): 85-90.

Micó, C., Peris, M., Sánchez, J. and Recatalá, L. (2006). Heavy metal content of agricultural soils in a Mediterranean semiarid area: the Segura River Valley (Alicante, Spain). Span. J. Agric. Res., 4(4): 363-372.

On, Z. L., Yang, X. E. and Stoffella, P. J. (2005). Trace elements in agroecosystems and impacts on the environment. J Trace Elem Med Biol, 19(2-3): 125-140.

Tscherko, D., Kandeler, E. and Bárdossy, A. (2007). Fuzzy classification of microbial biomass and enzyme activity in grassland soils. Soil Biol. Biochem., 39: 1799-1808.

Singh, J. and Kalamdhad, A. S. (2011). Effects of heavy metals on soil, plants, human health and aquatic life. IJEST, 1(2): 15-21.

Berthelin, J., Munier-Lamy,C. and Leyval, C. (1995). Effect of microorganisms on mobility of heavy metals in soils. In: Huang PM, Berthelin J, Bollag JM, McGill WB, Page AL, (editors).Metals, Other Inorganics, and Microbial Activities (Environmental impacts of soil component interactions, vol 2. Boca Raton (FL): Lewis. Pp. 3-17.

Juste, C. (1988). Appre'ciation de la mobilite' et de la biodisponibilite' des e' le'ments en traces du sol. Science du Sol. 26:103-112.

Miller, G.L. (1959). Use of dinitrosalicylic acid for determination of reducing sugar. Anal. Chem.

31: 426-429. 